\title{
Distribution, group characteristics and movements of the Critically Endangered Maui's dolphin Cephalorhynchus hectori maui
}

\author{
Marc Oremus ${ }^{1}$, Rebecca M. Hamner ${ }^{1,2}$, Martin Stanley ${ }^{3}$, Phillip Brown ${ }^{3}$, \\ C. Scott Baker ${ }^{1,2}$, Rochelle Constantine ${ }^{1, *}$ \\ ${ }^{1}$ School of Biological Sciences, University of Auckland, Auckland 1142, New Zealand \\ ${ }^{2}$ Marine Mammal Institute and Department of Fisheries and Wildlife, Oregon State University, Newport, Oregon 97365, USA \\ ${ }^{3}$ Department of Conservation, Auckland Area Office, Auckland 0744, New Zealand
}

\begin{abstract}
Maui's dolphin Cephalorhynchus hectori maui is one of the most endangered subspecies of mammals, and yet its ecology is poorly known, partly because of the difficulty in following individuals throughout their range and over time. Here we combined group sightings $(n=45)$ from 23 boat surveys and genotype recaptures from biopsy samples ( $\mathrm{n}=73,20$ microsatellite loci) collected over 2 summers (2010 and 2011) to investigate along-shore distribution, group characteristics and individual movements of Maui's dolphins. We found a clumped distribution extending along $139 \mathrm{~km}$ of coastline, with the highest density of dolphins between Manukau Harbour and south of Port Waikato, New Zealand. As recapture events $(n=32)$ revealed movements throughout most of their range, we suggest that the clumped distribution is driven by patchy food resources and/or social factors rather than by site fidelity. Mean group size was $4.7(\mathrm{SD}=3.0)$, with several large aggregations ( $\geq 8$ dolphins) containing a higher proportion of calves than smaller groups and thus probably acting as nursery groups. Group composition by sex was different in large and small groups, with more adult females in large groups. The majority of small groups contained individuals of both sexes, which contrasts with the pattern of sex segregation described in the South Island, New Zealand. A conservative estimate indicates that the mean along-shore range for Maui's dolphins is at least $35.5 \mathrm{~km}$, suggesting similarity to Hector's dolphins. However, some aspects of Maui's dolphin ecology as described here might have been affected by the recent history of population decline and low abundance.
\end{abstract}

KEY WORDS: Spatial distribution · Endangered species · Maui's dolphin · Cephalorhynchus hectori

\section{INTRODUCTION}

The Hector's dolphin Cephalorhynchus hectori is endemic to the coastal waters of New Zealand, showing the most limited range of any marine cetacean other than the vaquita Phocoena sinus (Reeves et al. 2008). Two subspecies are currently recognized on the basis of morphological and genetic evidence (Pichler et al. 1998, Baker et al. 2002): the South Island population retains the common name of Hec- tor's dolphin C. hectori hectori, and the North Island population is now referred to as Maui's dolphin $C$. hectori maui. The conservation status of the Maui's dolphin is of particular concern since its current population size is estimated at 55 individuals (Hamner et al. 2012a). The population has been declining since the 1960s mainly because of substantial by-catch mortality in gillnet fisheries; today, the population is thought to be only a fraction of its original size (Martien et al. 1999, Slooten et al. 2000, Baker et al. 2012). 
Consequently, the subspecies has been classified as Critically Endangered by the International Union for the Conservation of Nature (Reeves et al. 2008) and nationally critical under the New Zealand Threat Classification (Baker et al. 2010).

Maui's dolphins are restricted in their range to the west coast of the North Island, but historical records of strandings and sightings suggest that their distribution has contracted over the last 100 yr (Russell 1999, Dawson et al. 2001). Recent systematic surveys and reported sightings indicate that their current distribution extends from Kaipara Harbour to Kawhia Harbour (a distance of approximately $190 \mathrm{~km}$ ), with occasional sightings as far south as New Plymouth (Du Fresne 2010; Fig.1). However, distribution of the subspecies is non-homogenous, with the highest concentration within a $40 \mathrm{~km}$ stretch of coast, between Manukau Harbour and Port Waikato, in the centre of the subspecies' range (Reeves et al. 2008, Du Fresne 2010). The dolphins are primarily observed within 2 $\mathrm{km}$ of the coastline (Ferreira \& Roberts 2003, Slooten et al. 2005), but multiple sightings have confirmed that they also occur further offshore, extending out to the $7 \mathrm{n}$ mile $(13 \mathrm{~km}$ ) set-netting ban between Maunganui Bluff to Pariokariwa Point and (Du Fresne 2010, Fig.1).

The ecology of Hector's dolphins in the South Island has been well studied in the last few decades (Dawson 2009), but in comparison, little is known about the group characteristics and individual movements of Maui's dolphins. One reason for this is the relative absence of distinctive, long-term natural marks on the back and dorsal fin of this subspecies (the mark rate), which appears on only $10 \%$ of the individuals (M. Oremus unpubl. data). This is similar to the mark rate for Hector's dolphins at Banks

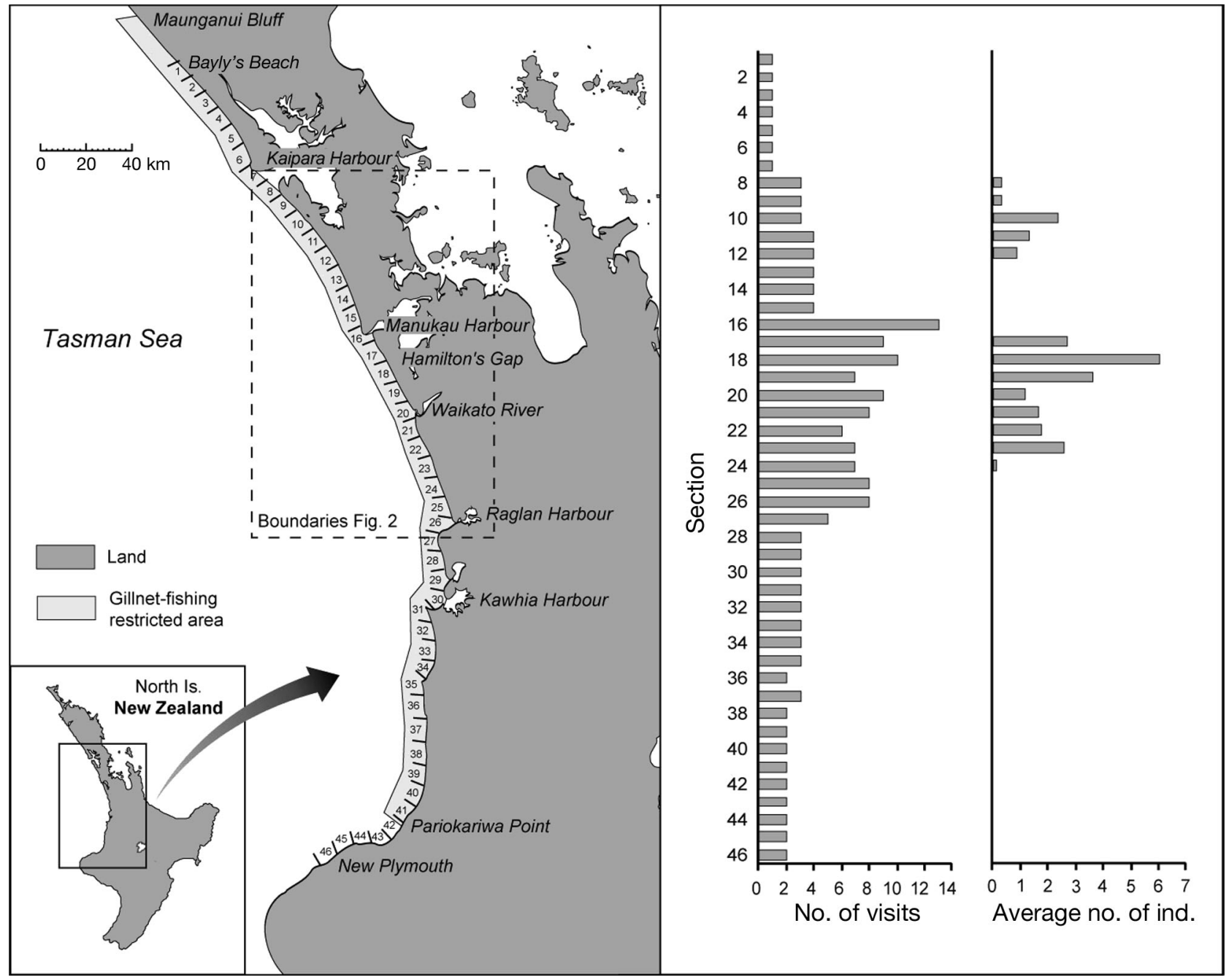

Fig. 1. Studied area showing the gillnet-fishing restricted area, including histograms of effort per section and average number of Cephalorhynchus hectori maui individuals encountered per section 
Peninsula (Gormley et al. 2005). Such a low mark rate, combined with a very small population size, limits the power of studies based on photo-identification. However, one way to overcome this problem is to use individual identification by DNA profiling or microsatellite genotyping, which provides a permanent and unique record for every individual. Skin samples as a source of DNA can now be collected from free-ranging small cetaceans using a lightweight biopsy dart fired from a veterinary rifle with a variable pressure valve, ensuring minimum physical impact and behavioural response (Krützen et al. 2002, Noren \& Mocklin 2012).

Systematic boat surveys were undertaken during February and March of 2 austral summers (2010 and 2011) on the west coast of New Zealand's North Island. The primary goal of the surveys was to collect biopsy samples from Maui's dolphins to provide new estimates of the current population size and level of genetic diversity (Hamner et al. 2012a). The combination of boat surveys and biopsy sampling provided an opportunity to investigate the distribution, group characteristics and movements of this Critically Endangered subspecies.

\section{MATERIALS AND METHODS}

\section{Surveys and data collection}

Systematic coastal boat surveys were undertaken on a $7 \mathrm{~m}$ rigid-hulled boat with twin $90 \mathrm{hp}$ outboard engines during 2 consecutive austral summer periods from 4 February to 2 March $2010(\mathrm{n}=12)$ and 14 February to 10 March 2011 ( $\mathrm{n}=11$ ). All surveys were conducted along the west coast of the North Island of New Zealand. In order to maximize the number of group encounters, effort was mostly (94\%) concentrated within $2 \mathrm{~km}$ from shore, where the summer concentration of Maui's dolphins is higher (Slooten et al. 2005). Surveys were initiated only in Beaufort seastates $\leq 2$. On occasion, the sea-state reached Beaufort 3 during the survey and on almost all occasions occurred during the inbound journey. In these situations we considered whether the conditions still allowed marine mammal sightings and continued effort on all occasions.

The surveys covered most of the current alongshore known range of Maui's dolphins, from North Kaipara to New Plymouth (Fig. 1). Four observers scanned $360^{\circ}$ around the vessel using the naked eye whilst the boat was travelling at $\sim 15$ to 20 knots. Once a group was sighted, the boat was immediately slowed down to less than 5 knots in order to approach the dolphins. A group was defined here as a spatial aggregation of dolphins that appear to be involved in a similar activity (Shane et al. 1986). For each group encounter, location using a global positioning system (GPS) was recorded, and group size was estimated visually using a minimum and maximum estimate when the exact size was uncertain. In such cases, the best estimate was calculated as the average between the minimum and maximum size. The number of calves (i.e. assumed to be less than 1 yr old and less than $1 \mathrm{~m}$ long; Webster et al. 2010) in the group were noted if present.

The group encounter was ended when dolphins could not be approached any more at slow speed or when we visually estimated that we had biopsied (see 'Molecular methods' for details) the majority of individuals over $1 \mathrm{yr}$ of age in the group and therefore the risk of biopsying the same individual again was considered extremely likely. Observers made sure that the dolphins were left behind when continuing the surveys, and if necessary, the boat was sped up to avoid being followed by some individuals. Group encounters were considered independent even though there was a possibility that individuals may be encountered more than once per survey as a consequence of changes in group composition over short periods of time. Even though dolphins were left behind before continuing with the survey, individuals could leave the group and join with other dolphins, thereby forming another group. However, this situation represented only a small proportion of our re-sightings of individual dolphins. Following Rayment et al. (2009), we summarized the spatial distribution of survey effort by dividing the coastline into sections of 5 nautical miles $(9.3 \mathrm{~km})$ in length and counting the number of times that each section was visited (Fig. 1). To avoid pseudo-replication, each section was counted once per day.

To investigate the relative along-shore density of Maui's dolphins, we calculated the number of groups and individuals encountered per visit in each of the sections, as described above. To minimize the likelihood of encountering groups more than once, only data recorded from the outbound journeys were used in the analyses of density and group characteristics.

\section{Molecular methods}

The Paxarms system ${ }^{\circledR}$ and lightweight biopsy darts (about $21.5 \mathrm{~g}$ ) were employed to collect biopsy samples (Krützen et al. 2002). Darts were equipped 
with a stainless steel biopsy head (5 mm diameter $\times$ $9 \mathrm{~mm}$ length) sterilized to minimize the risk of wound infection. This is, to our knowledge, the smallest cutting head available to collect cetacean biopsies. Efforts were made to minimize sampling individuals more than once, but only a few individuals had dorsal fin nicks which would have allowed individual identification of dolphins that had been sampled. Therefore, efforts were made before sampling to identify individuals with fresh biopsy marks; however, this was not possible if the dolphins only presented the side of their body that had not been biopsied to the observers. In addition, the very small size of the marks inflicted by the biopsies and the fast movements of Maui's dolphins meant it was not always possible to observe prior biopsy marks. Dolphin response to all sampling events was recorded to ascertain the level of responses (Noren \& Mocklin 2012, see Table S1 in the supplement at www.int-res. com/articles/suppl/n019p001_supp.pdf). Skin samples were stored in $70 \%$ ethanol at $-20^{\circ} \mathrm{C}$. To determine the sex and identity of individual dolphins, genomic DNA was extracted from each skin sample by digestion with Proteinase $\mathrm{K}$ followed by a standard phenol-chloroform extraction procedure (Sambrook et al. 1989), as modified for small samples (Baker et al. 1994). Sex was identified by co-amplification of X and Y (sry) chromosome specific markers (Gilson et al. 1998).

A total of 20 microsatellite loci previously developed for cetaceans were amplified and genotyped using an ABI3730. We used: 415/416 (Amos et al. 1993), EV14, EV37, EV94 (Valsecchi \& Amos 1996), GT23, GT211, GT575 (Bérubé et al. 2000), KWM9b, KWM12a (Hoelzel et al. 1998), MK5, MK6 (Krützen et al. 2001), PPHO110, PPHO130, PPHO142 (Rosel et al. 1999), SGUI06, SGUI07, SGUI16, SGUI17 (Cunha \& Watts 2007), TexVet5 (Rooney et al. 1999), and TtruGT48 (Caldwell et al. 2002). Amplification reactions for SGUI loci followed Cunha \& Watts (2007), and all others were set up as $10 \mu$ reactions containing $1 \times$ PCR II buffer, $1.5 \mathrm{mM} \mathrm{MgCl2}, 0.4 \mu \mathrm{M}$ each primer, $0.2 \mathrm{mM}$ dNTP, 0.125U Platinum Taq (Invitrogen) and 10 to $20 \mathrm{ng} \mathrm{ll}^{-1}$ DNA template and amplified using the following thermocycling profile: $93^{\circ} \mathrm{C}$ $2 \min _{i}\left(92^{\circ} \mathrm{C} 30 \mathrm{~s}, T_{\mathrm{A}} 45 \mathrm{~s}, 72^{\circ} \mathrm{C} 50 \mathrm{~s}\right) \times 15$; $\left(89^{\circ} \mathrm{C} 30 \mathrm{~s}\right.$, $\left.T_{\mathrm{A}} 45 \mathrm{~s}, 72^{\circ} \mathrm{C} 50 \mathrm{~s}\right) \times 20 ; 72^{\circ} \mathrm{C} 3 \mathrm{~min}$ (where $T_{\mathrm{A}}$ is the annealing temperature, see Hamner et al. (2012 a,b) for details). GENEMAPPER v. 3.7 (Applied Biosystems) was used to bin and visually verify the resulting peaks. Each amplification and sizing run included a negative control to detect contamination and a set of 7 internal control samples to standardize allele binning with previous genotyping runs and estimate genotyping error, as recommended by Bonin et al. (2004)

Probability of identity $\left(P_{\mathrm{ID}}\right)$ and probability of identity of siblings ( $P_{\text {IDsibs }}$ ) were calculated using the program GENALEX 6.1 (Peakall \& Smouse 2005). Microsatellite genotypes were then compared for the purposes of individual identification, both within and across sampling years, using the program CERVUS 3.0.3 (Kalinowski et al. 2007). Initial comparisons allowed for mismatching of up to 5 loci ('relaxed matching') to prevent false exclusion due to genotyping error. Relaxed matches were visually examined for potential allelic dropout, as well as matching sex and mtDNA haplotype, and repeated to confirm or correct the genotype as necessary.

\section{RESULTS}

\section{Effort and distribution}

Survey effort was evenly spread between the 2 field seasons (both covering a $\sim 3$ wk period during February and March each year) with a total of $178 \mathrm{~h}$ spent on the water and a total distance covered of $4010 \mathrm{~km}$ (Table 1). Most effort was concentrated within $2 \mathrm{~km}$ of shore, but we occasionally surveyed beyond this limit during the inbound journey (between 2 and $5 \mathrm{~km}$ from shore), representing about $6 \%$ of search effort. A total of 63 groups were encountered. Among these, 18 encounters occurred during the inbound journey. Because of the lack of distinctive marks, it was not possible to determine if these groups had already been seen on the outbound journey, and therefore, they were excluded from the analyses of density and group characteristics to avoid replication. This resulted in a minimum of 45 independent groups with an arithmetic mean (hereafter referred to as 'mean') of 2 groups encountered per

Table 1. Summary of survey effort and Maui's dolphin group encounters on outbound surveys. Surveys were conducted from 4 February-2 March 2010 and 14 February-10 March 2011

\begin{tabular}{|c|c|c|c|}
\hline & 2010 & 2011 & Total \\
\hline Number of surveys & 12 & 11 & 23 \\
\hline Hours on effort & 97 & 81 & 178 \\
\hline Distance travelled $(\mathrm{km})$ & 2117 & 1893 & 4010 \\
\hline Number of groups & 24 & 21 & 45 \\
\hline Mean number groups $\mathrm{d}^{-1}$ & 2.0 & 1.9 & 2.0 \\
\hline Mean group size (SD) & $5.1(3.4)$ & $4.1(2.5)$ & $4.7(3.0)$ \\
\hline
\end{tabular}


day (range $=0$ to 6 groups $\mathrm{d}^{-1}$ ). There was no significant difference in the rate of group encounters between the 2 years (Table 1). Dolphins were observed on $87 \%(n=20)$ of surveys, with only 3 unsuccessful surveys covering the northern (Kaipara Harbour to Bayly's Beach) and southern (Raglan Harbour to New Plymouth) limits of the survey area (Fig. 1). There were no sightings in any of the partially surveyed harbours, including Manukau, Raglan and Kaipara Harbours.

The northernmost sighting was just south of Kaipara Harbour $\left(36^{\circ} 28^{\prime} \mathrm{S}\right)$, while the southernmost sighting was north of Raglan ( $37^{\circ} 38^{\prime}$ S) (Fig. 2). Overall, the alongshore distribution was similar between the 2 surveys (Fig. 2), but in both years we found 2 areas with higher densities of sightings indicating a non-random distribution. The first area of high density was observed south of Kaipara Harbour between Sections 8 and $12\left(36^{\circ} 26^{\prime} \mathrm{S}\right.$ to $\left.36^{\circ} 47^{\prime} \mathrm{S}\right)$, where a mean of 0.5 groups and 1.2 dolphins were encountered per section (Fig. 1). A second area of high density extended from south Manukau Harbour to north of Raglan, between Sections 17 and $24\left(37^{\circ} 07^{\prime} \mathrm{S}\right.$ to $37^{\circ} 37^{\prime} \mathrm{S}$, Fig. 1). In this region, the group encounter rate was fairly similar to that of the south Kaipara Harbour region with 0.6 groups per section, but the mean number of individuals was much higher, with 3.3 dolphins encountered per section. Furthermore, within this second area, the distribution of group and individual density was found to be slightly bimodal with a first peak centred on Hamilton's Gap and a second one south of the Waikato River mouth (Fig. 1).

\section{Biopsy collection and processing}

A total of 73 skin samples were collected $(2010, \mathrm{n}=$ $37 ; 2011, \mathrm{n}=36$ ). Each sample was genotyped for an average of 19 loci and a low error rate of $0.4 \%$ was estimated initially, after which genotypes were repeated for confirmation or correction as necessary. We calculated an overall $P_{\mathrm{ID}}$ of $7.3 \times 10^{-8}$ and a $P_{\mathrm{IDsib}}$ of $4.0 \times 10^{-4}$. Given this low probability of a match by chance and the small size of the population, we assumed that samples with matching genotypes were replicates (i.e. genotype re-captures) of the same individual. Comparison of genotypes revealed that 32 biopsies were re-sampling events, giving a final total of 41 individual dolphins.

Genetic sex identification from the biopsy samples revealed that 45 samples were from females and 28 were from males. Although the difference is substantial, this ratio does not significantly deviate from a theoretical 1:1 ratio (exact binomial test of goodness of fit, $\mathrm{p}=0.06$ ). After excluding replicates, the sex ratio was 25 females and 16 males, which was also not significantly different from expectation $(\mathrm{p}=$ $0.211)$.

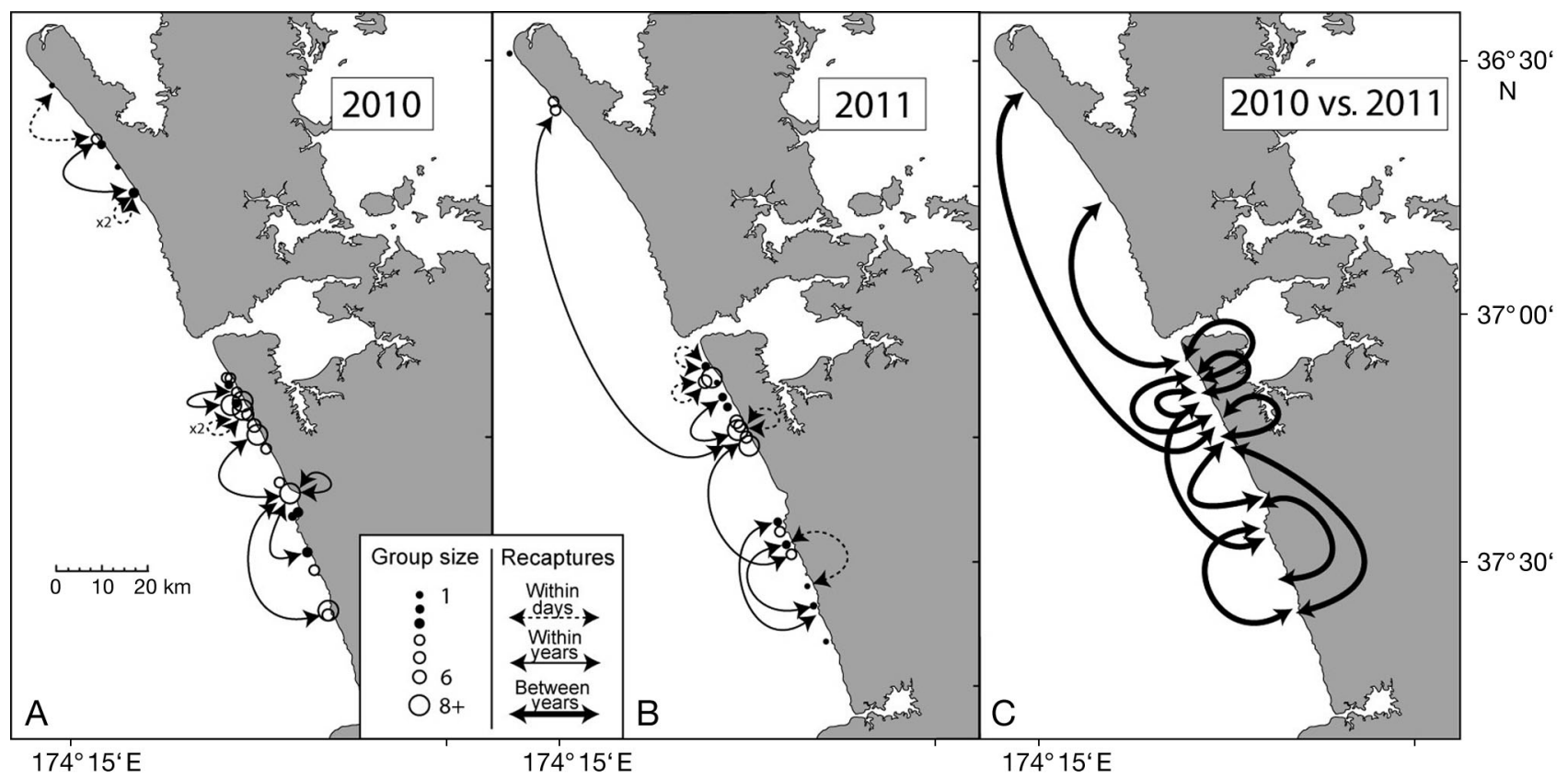

Fig. 2. Cephalorhynchus hectori maui. Distribution of Maui's dolphin group encounters in (A) 2010 and (B) 2011, including (C) group size information and individual movements within day, within year and between years as detected by genotype recaptures 


\section{Group characteristics}

Mean group size over the 2 years was estimated to be 4.7 individuals $(\mathrm{SD}=3.0$, median $=4$ ) based on best visual count estimates, ranging from 1 to 14 per group. Mean size was slightly larger in 2010 than 2011 (Table 1), but the difference was not significant (Kruskal-Wallis test, $H=0.664, \mathrm{p}=0.415)$. Large aggregations (defined here as $\geq 8$ dolphins, which represent the tail of the group size distribution; Fig. 3) were frequently observed, representing $25 \%$ of the groups in $2010(n=6)$ but only $14 \%$ in 2011 ( $n=3$ ) (Fig. 2). Most of these large aggregations were found in the high density area south of Manukau Harbour ( $n=7$ ), but they were also observed near the Waikato River mouth ( $\mathrm{n}=1$ ) and north of Raglan Harbour ( $=1)$. A larger proportion of solitary dolphins were observed in 2011 (19\%) compared to 2010 (8\%) (Fig. 3).

Calves were found in $23 \%(n=9)$ of groups. The mean size of groups containing calves was 8.2 (SD = 3.5), which was significantly larger than groups without calves $(H=11.905, \mathrm{p}<0.001)$, even when calves were excluded from the analysis (Kruskal-Wallis test, $H=5.923, \mathrm{p}<0.05)$. A total of 11 sightings of calves were recorded across the 2 surveys, with a maximum of 2 calves observed within the same group. Ten of these sightings were made in 2010 within 8 different groups, while only 1 sighting of 1 calf was made in 2011. It was not possible to determine how many unique calves were present among the 10 sightings made in 2010, but we can provide a minimum estimate of 3 calves in the population during that summer by combining sightings of groups encountered on a single outbound journey.

We used molecular sexing from biopsies to compare sex composition in large groups ( $\geq 8$ ind.) versus small groups. We collected a total of 15 samples from

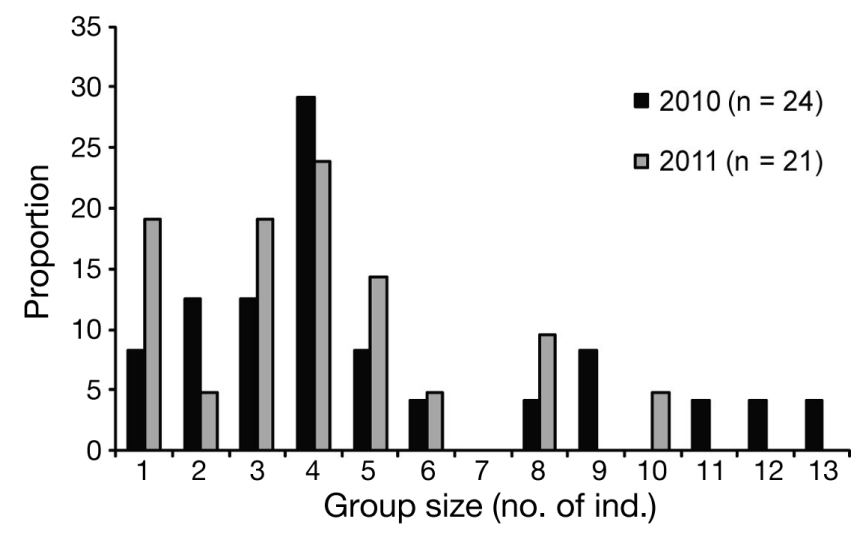

Fig. 3. Cephalorhynchus hectori maui. Group sizes of Maui's dolphins encountered in 2010 and 2011 (outbound journeys only) females and 5 from males in large groups, while 10 were from females and 7 from males in small groups. Despite a noticeable difference in these proportions, an exact binomial test of goodness of fit revealed that sex capture within large and small groups is not significantly different from null expectation ( $p=0.051)$. Since this result could be explained by small sample sizes, we also looked at sex composition with the inclusion of all 63 groups encountered during the study (i.e. including groups and samples from return trips). Doing so, we found that, in large groups, 23 samples were from females and 8 from males (ratio 2.8:1), while in small groups, 24 were from females and 18 were from males (ratio 1.3:1). In this case, exact binomial test indicates significant difference $(p<0.05)$ in sex composition according to group size.

Partial information on group sex composition was obtained from 13 unique groups from which we sampled more than 1 individual $($ mean $=2.4$, range $=$ 2 to 5). Overall, we identified males and females together within 8 groups $(62 \%)$. According to group size, we found that $67 \%$ of large groups and $57 \%$ of small groups were composed of individuals from both sexes.

\section{Movements of individuals}

Individual movements were documented by examining the sampling locations of replicate samples from the same individual. On 9 occasions, re-sampling happened within the same day (Fig. 2, see Table S2 in the supplement at www.int-res.com/articles/suppl/ n019p001_supp.pdf). Distances between same day re-samples ranged from $0.32 \mathrm{~km}$ within $13 \mathrm{~min}$ to $11.33 \mathrm{~km}$ within $2.5 \mathrm{~h}$ (Table S2). Distances between recaptures within years but on different days $(n=11)$ ranged from $0.91 \mathrm{~km}$ for an individual re-sampled $2 \mathrm{~d}$ later to $78.62 \mathrm{~km}$ for an individual re-sampled $19 \mathrm{~d}$ later (Fig. 2, Table S2). There was no correlation between distance and number of days between re-sampling events $\left(R^{2}=0.158, p=0.226\right)$. Dolphins showed no clear direction of movement, with individuals moving both north and south. There was no significant difference in the within-year distance travelled for males and females (Kruskal-Wallis test, $H=1.5, \mathrm{p}$ $=0.221$ ).

Longer-term individual movements inferred from re-samples between years $(n=12)$ were of a similar scale to the short-term within-year movements, ranging from $0.88 \mathrm{~km}$ over $372 \mathrm{~d}$ to $80.43 \mathrm{~km}$ over $375 \mathrm{~d}$ (Fig. 2, Table S2). There was no significant difference in the mean distances between within-year re-sam- 
pling (excluding within-day re-sampling) and between-year re-sampling (Kruskal-Wallis test, $H=$ $0.124, p=0.725)$. The individual sampled across the greatest distance was a female who travelled from south of Kaipara Harbour to south of Manukau Harbour. Interestingly, in 2011, she travelled back to south of Kaipara Harbour within 19 d. There was no significant difference in the between-year distance travelled for males and females $(H=0.321, \mathrm{p}=0.571)$.

A total of 6 dolphins ( $\mathrm{n}=3$ females, $\mathrm{n}=3$ males) were genetically recaptured on $3(n=5)$ or $4(n=1) d$. These were used to assess the minimum along-shore home range for Maui's dolphins. The mean distance between the 2 most extreme locations for these individuals was $35.50 \mathrm{~km}(\mathrm{SE}=4.03)$.

\section{DISCUSSION}

The distribution pattern of Maui's dolphins was found to be very similar over the 2 summers of our study (Figs. 1 \& 2); it indicates that their current core area of near-shore distribution extends along a $139 \mathrm{~km}$ stretch of coast from Kaipara Harbour to north of Raglan Harbour in the south, at least during the summer months. This distribution is largely in agreement with Du Fresne (2010), who synthesized results from surveys on the distribution of Maui's dolphins conducted between 2000 and 2009. However, Du Fresne (2010) indicated that Maui's were regularly observed as far south as Kawhia Harbour, whilst in our study the southernmost sightings were north of Raglan Harbour despite reasonable search effort further south in primarily good weather conditions ( $\leq$ Beaufort 2) (Fig. 1). Although we recognized that opportunistic sightings of Maui's dolphins are still occurring just south of Raglan Harbour, our results suggest that the current core area of near-shore distribution might be smaller than previously assessed. It must be noted that sporadic sightings and by-catch events of Maui's or Hector's dolphins are still occurring in the Taranaki region, but the subspecies status for these is largely unresolved. Nevertheless, there is a need to monitor the status of the species in this area. Further contraction of the core distribution range is not unexpected considering that their population size might still be declining (Baker et al. 2012). The hypothesis that a low number of resident individuals occur only at the limits of the subspecies range (Du Fresne 2010) seems less likely now that we have shown that Maui's dolphins commonly travel long distances within their current range. Therefore, the dolphins found along the coastline between
Taranaki and Wellington will prove to be extremely interesting in the future, and we suggest that surveys of this area be a priority.

The highest concentration of dolphins within the core area was found between Manukau Harbour and south of Port Waikato, confirming previous findings (Reeves et al. 2008). Our estimates of group and individual density were corrected by the number of visits to each section of the range, so this pattern is not due to the search effort being more intensive in this area, a concern that was expressed in previous surveys (Du Fresne 2010). The absence of sightings in the surveyed harbours, and in particular Manukau Harbour, supports other findings that these habitats are used only occasionally by Maui's dolphins (Rayment et al. 2011).

The sightings made during our surveys suggest a clumped distribution within the subspecies' core area (Fig. 1). Indeed, a gap in distribution was observed between Muriwai Beach and Manukau Harbour despite the fact that this area was covered multiple times over the 2 surveyed periods (Fig. 1). This result was surprising since previous studies conducted during summertime typically found a substantial number of groups within this area (Ferreira \& Roberts 2003, Slooten et al. 2005). The reason for the absence of sightings during our surveys is unknown. Maui's dolphins are at least crossing the zone from time to time, since multiple movements were documented between south Manukau and the northern part of the range. However, a shift in distribution related to further decline in abundance in recent years is an alternate explanation for this pattern, and therefore, further systematic surveys should be conducted in this area.

Further clumping in distribution was evident within the core area, with a peak south of Manukau Harbour, roughly in front of Hamilton's Gap, and a peak south of the Waikato River mouth (Fig. 1). This pattern was not described in previous studies, although sightings from these surveys seem to indicate a similar trend (Du Fresne 2010). Overall, the clumped distribution could be a reflection of site fidelity in Maui's dolphins, with some areas being more densely inhabited than others. However, the analysis of movements using genetic capture-recapture events shows multiple exchanges between the high and low density areas and, thus, poor support for site fidelity. In fact, long-distance movements by males and females supports the findings that there is no population genetic structure within Maui's dolphins' current range (Hamner et al. 2012b). Instead of population substructure, we suggest that the distribution of Maui's dolphins along the coast is most 
likely driven by uneven density of food resources and/or social factors such as mating behaviour or groups joining to reduce the risk of predation.

Assessment of the minimum along-shore home range for Maui's dolphins (35.50 km) was marginally larger than the mean home range estimated for Hector's dolphins at Bank Peninsula (33.01 km, Rayment et al. 2009), which suggests no major difference between the 2 subspecies. However, our estimate is conservative since it is based on only 3 or 4 sightings per individual compared to 10 or more sightings used by Rayment et al. (2009) to estimate the Hector's dolphin range at Banks Peninsula. The size of an individual's or a population's home range is often influenced by prey distribution and productivity, with species in areas of high productivity showing smaller home ranges than species in areas of low productivity (Harestad \& Bunnel 1979). However, demographic changes may be another factor influencing the home range of individuals from a depleted population such as Maui's dolphins. It has been shown in other species that a lower density of potential breeding mates could result in increased home ranges of individuals in search of mating opportunities (Loveridge et al. 2009).

Our investigation of group characteristics also gave some interesting insights into Maui's dolphin ecology. We found that groups with calves were significantly larger than groups without calves. This pattern points to the formation of nursery groups where adults associate to form larger aggregations than usual in the presence of calves. Large groups were also found to have a sex-ratio bias toward adult females. This supports results from Banks Peninsula, where all adult Hector's dolphins associating with mothers and calves appear to be females (Webster et al. 2009). However, some males were also biopsied within large groups of Maui's dolphins (although in smaller proportions than females), indicating that, within this subspecies, adults in the presence of calves are not exclusively female. The number of calf sightings was much more prevalent in 2010 (n $=10)$ than in 2011 ( $\mathrm{n}=1)$, and although it was not possible to determine the exact number of unique calves encountered in 2010, a minimum estimate of 3 calves suggests that there was a difference between the 2 research periods. This differ- ence is unlikely to be due to a seasonal effect since both surveys were conducted at almost the same time of year, though we cannot fully discount this possibility. Female Hector's dolphins are known to have a 2 to 3 yr calving interval (Slooten \& Lad 1991), which is likely to be similar in Maui's dolphins. Therefore, alternative explanations could be a difference in yearly calving rates with synchronized calving or differences in calf mortality between years. Given the status of Maui's dolphins, this question should be investigated further. Note that synchronized calving could be favoured as a strategy against predator pressure, especially in a depleted population where females form nursery groups and do not reproduce every year.

Webster et al. (2009) suggested that Hector's dolphin groups are highly segregated by sex, in particular small groups ( $\leq 5$ ind.) were found to contain both male and female adults only $9 \%$ of the time. Here, evidence from biopsy sampling show that at least $57 \%$ of small groups contained both males and females, and this result is conservative as we only partially sampled the groups (36\% of individuals sampled per group with at least one biopsy). This minimum estimate suggests that composition of small groups in Maui's dolphins differs from the pattern observed in Hector's dolphins at Banks Peninsula. Difference in sex composition within groups could reflect a different pattern of social organisation for both subspecies.

The mean group size during our study was substantially larger than previous estimates for Maui's dolphins derived from aerial surveys (Table 2). The

Table 2. Summary of mean group size estimates (with SD in parentheses) from previous research on Maui's dolphins. Coastal habitat is defined here as the stretch of water extending from the coastline to $9.3 \mathrm{~km}$ offshore. Offshore habitat is defined as the area between the coastline and up to $9.3 \mathrm{~km}$ offshore

\begin{tabular}{|c|c|c|c|c|c|}
\hline Source & Survey years & Season & $\begin{array}{l}\text { Survey } \\
\text { type }\end{array}$ & Habitat & $\begin{array}{l}\text { Mean group } \\
\text { size (SD) }\end{array}$ \\
\hline $\begin{array}{l}\text { Ferreira \& Roberts } \\
\text { (2003) }\end{array}$ & $\begin{array}{l}2000 / 01 \& \\
2001 / 02\end{array}$ & Dec- Mar & Aerial & Coastal & 2.53 \\
\hline Slooten et al. (2006) & 2004 & Jan & Aerial & $\begin{array}{l}\text { Coastal } \\
\text { Offshore }\end{array}$ & 1.43 \\
\hline $\begin{array}{l}\text { W. Rayment \& S. Du } \\
\text { Fresne unpubl. }\end{array}$ & 2007 & Oct & Aerial & $\begin{array}{l}\text { Coastal } \\
\text { Offshore }\end{array}$ & $1.31(0.48)$ \\
\hline $\begin{array}{l}\text { S. Childerhouse et al. } \\
\text { unpubl. }\end{array}$ & 2008 & May & Aerial & $\begin{array}{l}\text { Coastal } \\
\text { Offshore }\end{array}$ & $1.2(0.4)$ \\
\hline $\begin{array}{l}\text { T. Webster \& } \\
\text { C. Edwards unpubl. }\end{array}$ & 2008 & Mar & Aerial & Coastal & $1.83(1.27)$ \\
\hline M. Stanley unpubl. & 2009 & Jun-Jul & Aerial & $\begin{array}{l}\text { Coastal } \\
\text { Offshore }\end{array}$ & 1 \\
\hline Present study & $2010 / 11$ & Feb-Mar & Boat & Coastal & $4.7(3.0)$ \\
\hline
\end{tabular}


reason(s) for this discrepancy is most likely due to differences in sampling methods. The fact that our boat surveys were strictly along-shore, in contrast to most aerial surveys, could reflect a tendency toward larger groups near the coastline. A preference for coastal and shallow waters has been shown for nursery groups in several species of delphinids (e.g. Mann et al. 2000), and we showed here that presumed nursery groups in Maui's dolphins are significantly larger. This behaviour could be driven by several factors such as predator avoidance, foraging strategy, or mating behaviours (Connor 2000). Secondary explanations for discrepancy in mean group size estimates are possible. Indeed, aerial surveys might be more prone to under-estimating group sizes by missing individuals, especially for Maui's dolphins which reach a maximum length of about $1.5 \mathrm{~m}$ and usually inhabit turbid waters (Dawson 2009). Conversely, boat attraction could bias group size estimates up when using boat-based surveys.

In conclusion, we have shown that, at least for the austral summer months of February and March, Maui's dolphins have a smaller frequently used core area than previously reported. This is of concern as there are only 2 main areas of high density sightings throughout their range. Despite these clumped areas of high density, Maui's dolphins were found to travel long distances over the subspecies' range. Therefore, it is absolutely necessary to maintain and maybe increase protection from anthropogenic threats throughout their entire range. Our results further suggest that several aspects of Maui's dolphins' ecology could be influenced by the precarious status of the population, strengthening the need for further monitoring and investigation of their population dynamics and social organisation.

Acknowledgements. Primary funding for the fieldwork was provided by the New Zealand Department of Conservation, Auckland Conservancy and the New Zealand Worldwide Fund for Nature (WWF), with supplemental funding from the New Zealand Marsden Fund and the U.S. Marine Mammal Commission Fund. Thanks to Karl McLeod, Clinton Duffy, Garry Hickman, Bryan Williams, Emma Carroll, Dorothea Heimeier, Kristina Hillock, Elliot Brown, Dion Patterson, Stephanie Watts and Callum Lilley for their help in the field and to Vivian Ward for her help with figures. We also thank local Maori (iwi) as well as the Department of Conservation Taranaki, Waikato, Kauri Coast, Warkworth, Maniapoto and Auckland Area offices, and their associated Conservancy areas for their support. Samples were collected under permit RNW/HO/2009/03 from the Department of Conservation to C.S.B, and University of Auckland Animal Ethics Protocol AEC/02/2008/R658.

\section{LITERATURE CITED}

Amos B, Schlötterer C, Tautz D (1993) Social structure of pilot whales revealed by analytical DNA profiling. Science 260:670-672

Baker CS, Slade RW, Bannister JL, Abernethy RB, Weinrich MT, Lien J, Urban J, Corkeron P, Calambokidis J, Vasquez O, Palumbi SR (1994) Hierarchical structure of mitochondrial DNA gene flow among humpback whales Megaptera novaeangliae, world-wide. Mol Ecol 3: 313-327

Baker AG, Smith ANH, Pichler FB (2002) Geographical variation in Hector's dolphin: recognition of new subspecies of Cephalorhynchus hectori. J R Soc NZ 32:713-727

Baker CS, Chilvers BL, Constantine R, DuFresne S, Mattlin RH, van Helden A, Hitchmough R (2010) Conservation status of New Zealand marine mammals (suborders Cetacea and Pinnipedia), 2009. NZ J Mar Freshw Res 44: 101-115

Baker CS, Hamner RM, Cooke J, Heimeier D, Vant M, Steel D, Constantine R (2012) Low abundance and probable decline of the critically endangered Maui's dolphins estimated by genotype capture-recapture. An Cons doi: 10.1111/j.1469-1795.2012.00590.x

Bérubé M, Jørgensen H, McEwing R, Palsbøll PJ (2000) Polymorphic di-nucleotide microsatellite loci isolated from the humpback whale, Megaptera novaeangliae. Mol Ecol 9:2181-2183

Bonin A, Bellemain E, Bronken Eidesen P, Pompanon F, Brochmann C, Taberlet P (2004) How to track and assess genotyping errors in population genetics studies. Mol Ecol 13:3261-3273

Caldwell M, Gaines MS, Hughes CR (2002) Eight polymorphic microsatellite loci for bottlenose dolphin and other cetacean species. Mol Ecol Notes 2:393-395

Connor RC (2000) Group living in whales and dolphins. In: Mann J, Connor RC, Tyack PL, Whitehead H (eds) Cetacean societies: field studies of whales and dolphins. University of Chicago Press, Chicago, IL, p 199-218

> Cunha HA, Watts PC (2007) Twelve microsatellite loci for marine and riverine tucuxi dolphins (Sotalia guianensis and Sotalia fluviatilis). Mol Ecol Notes 7:1229-1231

Dawson SM (2009) Cephalorhynchus dolphins. In: Perrin WF, Würsig B, Thewissen JGM (eds) Encyclopedia of marine mammals. Academic Press, Amsterdam, p 191-196

> Dawson SM, Pichler F, Slooten E, Russell K, Baker CS (2001) The North Island Hector's dolphin is vulnerable to extinction. Mar Mamm Sci 17:366-371

Du Fresne S (2010) Distribution of Maui's dolphin (Cephalorhynchus hectori maui): 2000-2009. DOC Research \& Development Series 322. New Zealand Department of Conservation, Wellington

Ferreira SM, Roberts CC (2003) Distribution and abundance of Maui's dolphins (Cephalorhynchus hectori maui) along the North Island west coast, New Zealand. DOC Research \& Development Series 322. DOC Science Internal Series 93. New Zealand Department of Conservation, Wellington

Gilson A, Syvanen M, Levine K, Banks J (1998) Deer gender determination by polymerase chain reaction: validation study and application to tissues, bloodstains, and hair forensic samples from California. Calif Fish Game 84: 159-169

Gormley AM, Dawson SM, Slooten E, Bräger S (2005) Capture-recapture estimates of Hector's dolphin abundance 
at Banks Peninsula, New Zealand. Mar Mamm Sci 21: 204-216

Hamner RM, Oremus M, Stanley M, Brown P, Constantine R, Baker CS (2012a) Estimating the abundance and effective population size of Maui's dolphins using microsatellite genotypes: 2010-11, with retrospective matching to 2001-07. New Zealand Department of Conservation, Auckland

Hamner RM, Pichler FB, Heimeier D, Constantine R, Baker CS (2012b) Genetic differentiation and limited gene flow among fragmented populations of New Zealand endemic Hector's and Maui's dolphins. Conserv Genet. doi:10. 1007/s10592-012-0347-9

Harestad AS, Bunnel FS (1979) Home range and body weight - a re-evaluation. Ecology 60:389-402

Hoelzel AR, Potter CW, Best PB (1998) Genetic differentiation between parapatric 'nearshore' and 'offshore' populations of the bottlenose dolphin. Proc Biol Sci 265: 1177-1183

Kalinowski ST, Taper ML, Marshall TC (2007) Revising how the computer program CERVUS accommodates genotyping error increases success in paternity assignment. Mol Ecol 16:1099-1106

Krützen M, Valsecchi E, Connor RC, Sherwin WB (2001) Characterization of microsatellite loci in Tursiops aduncus. Mol Ecol Notes 1:170-172

Krützen M, Barré LM, Möller LM, Heithaus MR, Simmer C, Sherwin WB (2002) A biopsy system for small cetaceans: darting success and wound healing in Tursiops spp. Mar Mamm Sci 18:863-878

Loveridge AJ, Valeix M, Davidson Z, Murindagomo F, Fritz H, Macdonald DW (2009) Changes in home range size of African lions in relation to pride size and prey biomass in a semi-arid savanna. Ecography 32:953-962

Mann J, Connor RC, Barre LM, Heithaus MR (2000) Female reproductive success in bottlenose dolphins (Tursiops sp.): life history, habitat, provisioning, and group size effects. Behav Ecol 11:210-219

Martien KK, Taylor BL, Slooten E, Dawson SM (1999) A sensitivity analysis to guide research and management for Hector's dolphin. Biol Conserv 90:183-191

Noren DP, Mocklin JA (2012) Review of cetacean biopsy techniques: factors contributing to successful sample collection and physiological and behavioral impacts. Mar Mamm Sci 28:154-199

Peakall R, Smouse PE (2005) GenAlEx 6: Genetic Analysis in Excel. Population genetic software for teaching and research. Australian National University, Canberra

Pichler FB, Dawson SM, Slooten E, Baker CS (1998) Geographic isolation of Hector's dolphin populations described by mitochondrial DNA sequences. Conserv

Editorial responsibility: Ana Cañadas,

Madrid, Spain
Biol 12:676-682

> Rayment W, Dawson S, Slooten E, Bräger S, Du Fresne S, Webster T (2009) Kernel density estimates of alongshore home range of Hector's dolphins at Banks Peninsula, New Zealand. Mar Mamm Sci 25:537-556

Rayment W, Dawson S, Scali S, Slooten E (2011) Listening for a needle in a haystack: passive acoustic detection of dolphins at very low densities. Endang Species Res 14: 149-156

Reeves RR, Dawson SM, Jefferson TA, Karczmarski L and others (2008) Cephalorhynchus hectori ssp. maui. In: IUCN 2011. IUCN Red List of Threatened Species. Version 2011.1.www.iucnredlist.org/details/39427/0

Rooney AP, Merritt DP, Derr JN (1999) Microsatellite diversity in captive bottlenose dolphins (Tursiops truncatus). J Hered 90:228-231

$>$ Rosel PE, France SC, Wang JY, Kocher TD (1999) Genetic structure of harbour porpoise Phocoena phocoena populations in the northwest Atlantic based on mitochondrial and nuclear markers. Mol Ecol 8:S41-S54

Russell K (1999) The North Island Hector's dolphin. MSc thesis, University of Auckland

Sambrook J, Fritsch EF, Maniatis T (1989) Molecular cloning: a laboratory manual, 2 edn Cold Spring Harbor Laboratory, Cold Spring Harbor, NY

Shane S, Wells RS, Würsig B (1986) Ecology, behavior and social organization of the bottlenose dolphin: a review. Mar Mamm Sci 2:34-63

Slooten E, Lad F (1991) Population biology and conservation of Hector's dolphin. Can J Zool 69:1701-1707

Slooten E, Fletcher D, Taylor BL (2000) Accounting for uncertainty in risk assessment: case study of Hector's dolphin mortality due to gillnet entanglement. Conserv Bio 14:1264-1270

Slooten E, Dawson SM, Rayment W, Childerhouse S (2005) Distribution of Maui's dolphin, Cephalorhynchus hectori maui. In: New Zealand Fisheries Assessment Report 2005/28. Ministry of Fisheries, Wellington

Slooten E, Dawson S, Rayment W, Childerhouse S (2006) A new abundance estimate for Maui's dolphin: What does it mean for managing this critically endangered species? Biol Conserv 128:576-581

- Valsecchi E, Amos W (1996) Microsatellite markers for the study of cetacean populations. Mol Ecol 5:151-156

> Webster TA, Dawson S, Slooten E (2009) Evidence of sex segregation in Hector's dolphin (Cephalorhynchus hectori). Aquat Mamm 35:212-219

> Webster T, Dawson S, Slooten E (2010) A simple laser photogrammetry technique for measuring Hector's dolphins (Cephalorhynchus hectori) in the field. Mar Mamm Sci 26:296-308

Submitted: February 24, 2012; Accepted: July 22, 2012

Proofs received from author(s): September 18, 2012 